УДК $78.03+787.5 / 787.6$

\author{
Наталія Василівна Хмель, \\ здобувач кафедри теорії музики та композиції \\ Одеської національної музичної академії імені А. В. Нежданової, \\ викладач кафедри народних інструментів
}

Дніпропетровської академії музики імені М. Глінки tusyaband@gmail.com

\title{
МЕТОД ГЕРМЕНЕВТИЧНОГО ПІДХОДУ ПРИ ТРАНСФОРМАЦІЇ ОРГАННИХ ХОРАЛЬНИХ ПРЕЛЮДІЙ Й. С. БАХА ДЛЯ БАНДУРИ
}

\begin{abstract}
Мета дослідження - виявити темброво-фактурні особливості трансформації та інтерпретації творів композиторів епохи бароко в перекладенні для струнно-щипкового українського народного інструмента - бандури. Методологія дослідження полягає у застосуванні компаративного методу в музиці, методу системного аналізу для дослідження потенціалу розширення засобів трансформації музики минулих сторічь, історичного методу для лінійного розгляду проблеми перекладення творів епохи бароко, методу узагальнення для формулювання висновків. Зазначений методологічний підхід дозволяє розкрити та проаналізувати основні принципи перекладення інструментальних творів доби бароко для бандури. Наукова новизна полягає у розширенні методів перекладення та обгрунтуванні основних засобів трансформації органних хоральних прелюдій Й. С. Баха при перекладенні для бандури. Висновки. На основі музично-виконавського аналізу органних хоральних прелюдій Й. С. Баха в перекладенні для бандури С. Овчарової можна зробити висновок, що трансформація творів епохи бароко для українського народного інструмента - бандури можлива, що доводить багатогранна звукова темброколористика та фактурні можливості інструмента. Отже, інтерпретація музичних шедеврів минулих сторічь на сучасній модифікованій бандурі підтверджує процес ї академізації та значно збагачує як навчальний, так і концертний репертуар представників бандурного мистеитва.
\end{abstract}

Ключові слова: темброво-фактурні особливості, трансформація, перекладення, епоха бароко, інтерпретація, герменевтика, органні хоральні прелюдіі. 
Khmel' Nataliya, degree-seeking student of the department of music theory and composition of the Odessa National A. V. Nezhdanova Academy of Music. teacher the department of Folk instruments of M. Glinka Dnipropetrovsk Academy of Music

Method of a hermeneutic approach in transformation of organ choral preludes of $J$. S. Bach for bandura

The purpose of the research is the revealing of timbre and texture features of the transformation and interpretation of the works of the Baroque composers in the arrangement for the stringed-plucked Ukrainian folk instrument bandura. The methodology of the research is to use a comparative method in music, a method of system analysis to study the potential of expanding the means of transforming music of past centuries, a historical method for linear consideration of the problem of arrangement of works of the Baroque epoch, a method of generalization for the formulation of conclusions. This methodological approach allows us to reveal and analyze the basic principles of the arrangement of instrumental works of the Baroque epoch for bandura. The scientific novelty is to expand the methods of arrangement and substantiation of the basic means of transformation of organ choral preludes of J. S. Bach during arrangement for bandura. Conclusions. On the basis of the musical performance of the organ choral preludes of $J$. S. Bach in the arrangement for bandura by S. Ovcharova, we can make a conclusion that the transformation of Baroque works for the Ukrainian folk instrument - bandura is possible, which is proved by the multifaceted sound timbre colouristics and texture possibilities of the instrument. So, the interpretation of musical masterpieces of the past centuries on modern modified bandura confirms the process of its academization and significantly enriches both the educational and concert repertoire of the representatives of the bandura art.

Keywords: timbre and texture features, transformation, arrangement, the Baroque epoch, interpretation, hermeneutics, organ choral preludes.

Хмель Наталия Васильевна, соискатель кафедры теории музыки и композиции Одесской национальной музыкальной академии имени А. В. Неждановой, преподаватель кафедры народных инструментов Днепропетровской академии музыки имени М. Глинки

Метод герменевтического подхода при трансформации органных хоральных прелюдий Й. С. Баха для бандури

Цель исследования - выявить темброво-фактурные особенности трансформации и интерпретации произведений композиторов эпохи барокко в переложении для струнно-щипкового украинского народного инструмента - бандуры. Методология исследования заключается в применении компаративного метода в музыке, метода системного анализа для исследования потенциала расширения средств трансформации музыки прошлых столетий, исторического метода для линейного рассмотрения проблемы переложение произведений эпохи барокко, метода обобщения для формулировки выводов. Указанный методологический 
подход позволяет раскрыть и проанализировать основные принципы переложения инструментальных произведений эпохи барокко для бандуры. Научная новизна заключается в расширении методов переложения и обосновании основных средств трансформации органных хоральных прелюдий И. С. Баха при переложении для бандуры. Выводы. На основе музыкально-исполнительского анализа органных хоральных прелюдий И. С. Баха в переложении для бандуры С. Овчаровой можно сделать вывод, что трансформация произведений эпохи барокко для украинского народного инструмента бандуры возможна, что доказывает многогранная звуковая темброколористика и фактурные возможности инструмента. Итак, интерпретация музыкальных шедевров прошлых веков на современной модифицированной бандуре подтверждает процесс ее академизации и значительно обогащает как учебный, так и концертный репертуар представителей бандурного искусства.

Ключевые слова: темброво-фактурные особенности, трансформация, переложение, эпоха барокко, интерпретация, герменевтика, органные хоральные прелюдии.

Актуальність теми дослідження. 3 50-х років XX сторіччя ведеться активна робота щодо вдосконалення конструктивних особливостей та технічних можливостей бандури (впровадження механізму переключення тональностей). В даній галузі активно працюють B. Тузиченко та I. Скляр (конструктор бандури київського типу), а також майстер, бандурист та педагог В. Герасименко (конструктор бандури-«львів’янки») [10, 61-62]. У 60-х роках в історії бандурного виконавства відбулася значна подія. Майстер-винахідник I. Скляр у співдружності з С. Баштаном, А. Омельченко та П. Івановим створили модифіковану конструкцію інструмента. Було винайдено хроматичну бандуру з механічним переключенням тональностей, завдяки чому з'явилась можливість грати лівою рукою не тільки на басах, але й на приструнках та виконувати твори в усіх 24 тональностях. Це дало поштовх у розвитку репертуару для бандури, технічні можливості якої стали значно ширше [1].

В різноманітті інструментального виконавського репертуару європейської академічної музики твори композиторів доби бароко представляються достатньо близькими до звучання бандури, з огляду на їх темброву поліваріантність, естетичну специфіку та концептуальність змісту. Саме барочна класика змістовно споріднена інструментальній специфіці бандури, яку відрізняє яскрава палітра тембрів, що відображає тематичну глибину іiі виконавського призначення. Таким чином, введення в бандурний репертуар творів барочної класики відіграє ам- 
бівалентну роль, а саме: сприяє як поширенню в сучасному концертному репертуарі класичних творів доби бароко, так й актуалізації широких можливостей бандури, що переживає сьогодні трансформацію своєї ролі в еволюційному становленні концертної культури.

Тож актуальність даної статті зумовлена потребою обгрунтування трансформаційних перетворень перекладення музичних творів епохи бароко для бандури, що обумовлено зростанням інтересу виконавців та слухачів як до самого інструмента так й до розширення його змістовних, стилістичних та й інтерпретаційних можливостей за рахунок введення в репертуарне коло кращих зразків музичної естетики академічного мистецтва минулого.

Аналіз останніх досліджень і публікацій. Проблема перекладення та виконання творів різних жанрів для народних інструментів і використання їх у навчально-виховному процесі була темою дослідження багатьох вітчизняних науковців, а саме I. Дмитрук «Жанр перекладу та його різновиди в сучасному бандурному мистецтві» [3]; С. Карася «Інтерпретація музики бароко на баяні (теоретико-виконавський аспект)» [4]; В. Дейнеги «Перекладення як процес переосмислення засобів оркестрової виразності» [2]; I. Теуту «Транскрипція в українському цимбальному мистецтві: історичний та теоретичний аспекти» [8] тощо. Утім представлені дослідження науковців із зазначеної проблематики все ж таки мають «білі плями» у розв’язанні актуальних проблем трансформації музичних творів при перекладенні для бандури, що потребує подальшого наукового осмислення.

Мета дослідження - виявити темброво-фактурні особливості трансформації та інтерпретації творів композиторів епохи бароко в перекладенні для струнно-щипкового українського народного інструмента - бандури.

Методологія дослідження полягає у застосуванні компаративного методу в музиці, методу системного аналізу для дослідження потенціалу розширення засобів трансформації музики минулих сторічь, історичного методу для лінійного розгляду проблеми перекладення творів епохи бароко, методу узагальнення для формулювання висновків. Зазначений методологічний підхід дозволяє розкрити та проаналізувати основні принципи перекладення інструментальних творів доби бароко для бандури.

Наукова новизна полягає у розширенні методів перекладення та обгрунтуванні основних засобів трансформації органних хоральних прелюдій Й. С. Баха при перекладенні для бандури. 
Виклад основного матеріалу дослідження. Виходячи із широкого кола фактичного матеріалу музичних творів минулих століть, а саме епохи бароко, їх перекладення, транскрипції та інших видів трансформації, виникає проблема їх змістовного та стильового тлумачення. В контексті даної роботи ми залучаємо поняття «герменевтика», що за своїм походження належить до філософського категоріального апарату. Ми розглядаємо даний термін з точки зору перетлумачення, переробки, перетворення, переосмислення первісного значення, відродження творів епохи бароко.

Термін «музична герменевтика» отримав розповсюдження в музичній культурі лише з початку XX сторіччя і був введений Г. Кречмаром у 1902 році. На його думку, герменевтика в музиці більш потрібна, ніж в інших галузях мистецтва, тому що музика не має прямих, виразних, ясних та реальних зв'язків зі всесвітом та природою [5]. «Герменевтика музична (від грецьк. - роз'яснюю) - вчення про тлумачення змісту музичного твору» $[9,465]$.

Органні хоральні прелюдії займають особливе місце в творчості Баха. Як відомо, композитор був дуже віруючою людиною, через це його життя та творчість тісно пов'язані з діяльністю у якості церковного музиканта. Віросповідання пояснює звертання Баха до протестантського хоралу, з яким він працює в самих різних жанрах протягом всього життя. Хорал стає невід'ємною складовою частиною музичної мови майстра. В музичній структурі органних мініатюр композитор використовує форми, які успадкував від його попередників, а саме I. Пахельбеля, Г. Бьома, Д. Букстехуде, Й. Рейнкена. К кінцю веймарського періоду у Баха складається власне бачення по відношенню до творчості своїх вчителів, він створює оригінальний новий тип - хоральну прелюдію із «Органної книжечки». В ній композитор задумав та здійснив ідеал хоральної прелюдії, «найбільш простий та одночасно досконалий» [11, 207-208]. Усього нараховується близько 150 хоральних прелюдій, які Бах об'єднав у чотири збірки. Особливе місце серед них займає згадана раніше «Органна книжечка», написана у Кьотені (найбільш ранній період - 1714-1716), що складається із 45 обробок; збірник «Клавірних вправ», що нараховує 21 обробку (деякі з них розраховані на органну інтерпретацію); 6 п’єс, надрукованих у 1747 році, які відомі під назвою «Шюблеровські хорали»; остання збірка органних обробок «18 хоралів» була підготовлена композитором незадовго до його смерті [7].

Кожен лютеранин знав мелодію хоралу напам'ять, в основі якого завжди лежав біблейський сюжет, розумів зміст та духовне 
значення, «вони входили в духовний світ людини як природний, необхідний, органічно «врослий» у психіку та свідомість елемент світовідчуття» $[6,22]$. Відомий хорал викликав у слухачів одразу декілька асоціацій, що були пов'язані з його змістом, конкретним епізодом біблейської історії, колом свят або ритуальним дійством, якому призначався цей хорал. Так, прикладом адаптування теми протестантського хоралу в якості музичної основи багаточастинного твору для оркестру є «Симфонія (3-голосна інтенція) a-moll», що заснована на хоралі «Christ lag in Todesbanden» («Христос лежав в пеленах смерті»). Даний хорал належить до пасхального кола, що відображено в його тексті та простежується в музичному змісті симфонії, яка включає в себе як образи печалі, скорботи, так і радість з приводу воскресіння Христа, а також славослів'я «Алілуя». Зміст хоралу: «Христос лежкв в пеленах смерті, що дані йому за наші гріхи. Він повстав і приніс нам життя. Саме тому ми повинні бути радісними, хвалити Господа та бути йому вдячними і співати: Алілуя, Алілуя!» [6, 22-23]. Представлений хорал буде нами проаналізований у якості прикладу трансформації інструментальної органної музики для бандури.

Хоральна прелюдія Й. С. Баха «Christ lag in Todesbanden», BWV№ 625 («Христос лежав в пеленах смерті») є однією з самих мініатюрних (12 тт.). При стислості масштабів тим більш вражає іiі тематична сконцентрованість, що дозволяє навіть визначити явище «монотемності» (гомогенності). Весь тематизм прелюдії випливає 3 одного інтонаційного витоку - секвентноподібного мотиву. У свою чергу, підгрунтям його стає складова частина провідної теми хоралу, що виведена (як в більшості хоральних прелюдій Баха) у верхній голос і вирує над всією багатоголосною тканиною. Це - плинний, поступовий секундовий рух в обсязі терції з перевагою низхідного устремління (мелодія типу catabasis), що в певній мірі відповідає змісту прелюдії та ії̈ тексту:

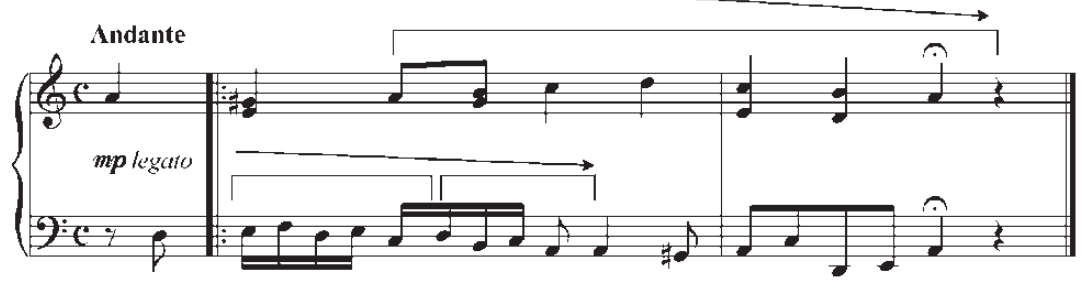


Основний мотив, переходячи з голосу в голос, отримує гранично насичений імітаційний розвиток в усіх супроводжуючих голосах, виходячи навіть у верхній голос (т. 7) і складаючи досить щільну фактуру. Таким чином, зберігаючи незмінною основну мелодію хоралу як константу, Бах розцвічує іiї фактурно, збагачуючи і ускладнюючи іiі тематичний потенціал.

Хоральна прелюдія «Christ lag in Todesbanden» монолітна, вона позбавлена контрастів, загальний рух і динаміка ії розвитку націлені на досягнення кульмінації наприкінці через ущільнення фактури, охоплення крайніх вершин діапазону $\left(\mathrm{a}^{2}-\mathrm{D}\right)$, збільшення динаміки до $f f$ і отримання в результаті типового барокового ефекту піккардійської терції, підсиленого прийомом арпеджіато і тривалої фермати.

Проаналізуємо ще один шедевр органних мініатюр великого майстра. Й. С. Бах Хоральна прелюдія «Із глибини благаю Тебе, Господи» («Aus der tiefe rufe ich», BWV № 745). Його зміст наступний: «Iз глибини благаю Тебе, Господи, Господи! Почуй голос мій. Нехай будуть вуха Твої внемлющі гласу мого благання». Ця хоральна прелюдія більш масштабна і розгорнута. В ній можна виділити три розділи подібно трьом куплетам з варіантно-варіаційним розвитком провідної теми протестантського хоралу. В такому випадку перший 8-тактний розділ (назвемо його умовно розділом А) виконує функцію свого роду «вступу». Йому властиві стриманість ( $p p)$, розміреність, рівномірність остинатних чвертей і навіть рівнопротяжність, пропорційність 2-тактових побудов-фраз:

1-2- тт. e-moll із зупинкою на домінантовій полукаденції;

3-4 тт. h-moll як результат зіставлення однойменних тональностей $\mathrm{H}-\mathrm{h}$;

5-6 тт. модулюючий в G-dur, паралельний основному e-moll;

7-8 тт. e-moll-E-dur.

Крайні голоси урівнюють один одного, створюючи своєрідний «протирух» мелодичної лінії сопрано і баса, тотожних за ритмікою.

Другий розділ (B, 11 тт.) базується на типовому «прелюдійному» архетипі. Провідна тема хоралу фактурно збагачується, насичується допоміжними контрапунктуючими голосами.

Третій розділ подібний до «синтетичної» репризи: основна хоральна тема знов рельєфно заявляє у верхньому шарі, як це було в початковому розділі. Але в середніх голосах продовжується «прелюдійна» фактура, ритмічна пунктирна формула (тт. 21, 23), що зближує останній розділ з попереднім. Третій розділ значно розширений і 
динамізований, оскільки до нього приєднується заключний, кодовий розділ, найбільш насичений за звучанням і ущільнений фактурно. За достатньо розвиненим гармонічним і тональним планом він становить кульмінаційний етап розвитку прелюдії: e-a-G-C-e-a-e-E-e.

Характерною особливістю перекладення органних хоральних прелюдій, здійснених С. Овчаровою для бандури, є збереження стилю та форми фактурного викладу музичного матеріалу оригіналу, що забезпечує еквівалентність головних засобів художньої виразності в новій темброво-фактурній інтерпретації. Звернемо увагу, що тональності прелюдій не потребують транспозиції, оскільки вони входять в коло зручних тональностей на бандурі та діапазон творів не виходить за межі бандурного. Але все ж таки при роботі з органним оригіналом відбулась певна трансформація:

- при перекладенні органного твору для бандури ми зазвичай записуємо його на двох нотоносцях, в той час як органна фіксація музичного матеріалу реалізується на трьох рядках;

- увесь музичний матеріал, який в органній інтерпретації грається на педальній клавіатурі, при перекладенні на бандуру передається в ліву руку, яка у свою чергу виконує партію або у великій октаві, або у малій харківським способом гри (або перекидкою);

- при переробці застосовується метод перенесення окремих голосів або цілих мелодичних ліній в іншу октаву, не порушуючи при цьому голосоведення, що пов'язано з технічними можливостями бандури;

- для більш зручного донесення характеру твору автор перекладення пристосовує фактуру оригіналу під бандурне звучання, вдаючись іноді до незначних спрощень, а саме: випущення деяких середніх голосів; перенесення мелодичної лінії із лівої руки оригіналу в праву руку бандури; виконання партії педальної клавіатури правою рукою, якщо це дозволяє фактурне викладення твору; розшифрування деяких прикрас тощо;

- застосовується метод редукції (розрідження фактури) та ампліфікації (згущення фактурного викладу) при роботі з оригіналом.

Висновки. На основі вищенаведеного музично-виконавського аналізу органних хоральних прелюдій Й. С. Баха в перекладенні для бандури С. Овчарової можна зробити висновок, що трансформація творів епохи бароко для українського народного інструмента бандури можлива, що доводить багатогранна звукова темброколористика та фактурні можливості інструмента. Отже, інтерпретація 
музичних шедеврів минулих сторічь на сучасній модифікованій бандурі підтверджує процес іiі академізації та значно збагачує як навчальний, так і концертний репертуар представників бандурного мистецтва.

\section{СПИСОК ЛІТЕРАТУРИ}

1. Гуменюк А. Иван Скляр. Москва: Советский композитор, 1963. 33 с.

2. Дейнега В. М. Перекладення як процес переосмислення засобів оркестрової виразності: автореф. дис. ... канд. мист-ва: 17.00.03 / Одес. держ. муз. акад. ім. Антоніни Нежданової. Одеса, 2006. 19 с.

3. Дмитрук I. І. Жанр перекладу та його різновиди в сучасному бандурному мистецтві: автореф. дис. ... канд. мист-ва: 17.00 .03 / Львів. нац. муз. акад. ім. Миколи Лисенко. Львів, 2009. 18 с.

4. Карась С. О. Інтерпретація музики бароко на баяні (теоретико-виконавський аспект): автореф. дис. ... канд. мист-ва: 17.00 .03 / Львів. держ. муз. акад. ім. Миколи Лисенка. Львів, 2006. 20 с.

5. Музыкальная герменевтика. URL: http://www.etheroneph.com/ audiosophia/144 muzykalnaya-germenevtika.html (дата обращения 09.01.2016).

6. Носина В. Б. Символика музыки И. С. Баха / Международные курсы высшего художественого мастерства пианистов памяти С. В. Рахманинова. Тамбов. 1993. 105 с.

7. Органное творчество Баха. Лекции по музыкальной литературе musike. ru: Баx. URL: http://musike.ru/index.php?id=10 (дата обращения 09.01.2016).

8. Теуту I. П. Транскрипція в українському цимбальному мистецтві: історичний та теоретичний аспекти: автореф. дис. ... канд. мист-ва: 17.00.03 / Інстит. мис-ва, фольклор. та етнол. ім. Максима Рильського. Київ, 2016. 19 с.

9. Чередниченко Т. В. Музыкальная герменевтика. Музыкальный энииклопедический словарь / гл. ред. Г. В. Келдыш. Москва: Советская энциклопедия, 1990. C. 465

10. Чернета Т. Наслідування автентичних кобзарських традицій у сучасній музичній практиці. Мистецтвознавчі записки: зб. наук. праць. Київ, 2009. Вип. 15. С. $58-63$.

11. Швейцер А. Иоганн Себастьян Бах. Москва: Музыка, 1965. 728 с.

\section{REFERENCES}

1. Gumenyuk, A. (1963). Ivan Sklyar. Moscow: Soviet composer [in Ukrainian].

2. Deynega, V. M. (2006). Arrangement as a process of rethinking of orchestral expression means. Extended abstract of candidate's thesis. Odessa: ODMA named A. V. Nezhdanova [in Ukrainian].

3. Dmitruk, I. I. (2009). Genre of transposition and its variants in modern bandura art. Extended abstract of candidate's thesis. Lviv: LNMA named M. V. Lysenko [in Ukrainian]. 
4. Karas, S. O. (2006). Interpretation of baroque music on bayan (theoretical-performing aspect). Extended abstract of candidate's thesis. Lviv: LSMA named M. V. Lysenko [in Ukrainian].

5. Musical hermeneutics. Retrieved from http://www.etheroneph.com/audiosophia/144 muzykalnaya-germenevtika.html [in Ukrainian].

6. Nosina, V. B. (1993). Symbolics of music by I. S. Bach. International courses of the highest artistic mastery of pianists by memory of S. V. Rakhmaninov. Tambov [in Ukrainian].

7. Organ creation of Bach. Lectures of musical literature musike.ru: Bach. Retrieved from http://musike.ru/index.php?id=10 [in Ukrainian].

8. Teutu, I. P. (2016). Transcription in the ukrainian cymbal art: historical and theoretical aspects. Extended abstract of candidate's thesis. Kyiv: Institute of art, folklore and ethnology named Maxim Rylsky [in Ukrainian].

9. Cherednichenko, T. V. (1990). Music hermeneutics. G. V. Keldysh (Eds.), Music encyclopedic dictionary (p. 465). Moscow: Soviet encyclopedia [in Ukrainian].

10. Cherneta, T. (2009). Implication of authentic kobzar traditions in modern music practice. Art criticism notes: collection sciences works (issue 15), (pp. 5863). Kyiv [in Ukrainian].

11. Schweitzer, A. Johann Sebastian Bach. Moscow: Music [in Ukrainian].

Стаття надійщла до редакції 08.06.2016

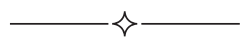

УДК $78.03+78.05 / .07$

Володимир Петрович Клещуков, здобувач кафедри історії музики та музичної етнографії

ОНМА ім. А. В. Нежданової

\section{ВЗАЕМОДІЯ ХОРЕОГРАФА ТА КОНЦЕРТМЕЙСТЕРА ЯК ОСНОВА ІНТЕРПРЕТАЦІЙНОГО ПРОЦЕСУ}

Мета роботи. Устатті аналізуються специфічні параметри творчої взаємодії концертмейстера та хореографа в репетиційному та концертно-виконавському процесі на основі спільних когнітивно-виконавських засад. Методологія дослідження полягає в застосуванні загальнонаукових підходів і принципів - системного, синергетичного, історичного, еволюційного підходів, принципу додатковості, а також компаративного, естетико-культурологічного, історичного методів, музикознавчого підходу. Наукова новизна роботи полягає в розширенні уявлень про феноменологічні аспекти спільної музично-хореографічної інтерпретації y мистецтвознавчому та виконавсько-теоретичному аспектах. Bu-

(C) Клещуков В. П., 2016 